\title{
EVALUATION OF BOTANICAL EXTRACTS FOR THE MANAGEMENT OF GREATER WAX MOTH, Galleria mellonella Linnaeus (Lepidoptera: Pyralidae) UNDER STORED CONDITIONS
}

\author{
Büyük Mum Güvesi, Galleria Mellonella Linnaeus'un (Lepidoptera: Pyralidae) \\ Depolanmiş Durumda Yönetimi İçin Botanik Özütlerin Değerlendirilmesi
}

\author{
Sabatina PAULRAJ1*, Umapathy GOVINDASAMY², Saravanan AYYASWAMI \\ PERNAMALLUR ${ }^{3}$
}

\begin{abstract}
1*Department of Agricultural Entomology, Tamil Nadu Agricultural University, Coimbatore 641-003, Tamil Nadu, INDIA, Yazışma Yazarı/Corresponding author E-mail: sabitinajustin@gmail.com, ORCID No: 0000-0002-8398-7108

${ }^{2}$ Department of Agricultural Entomology, Centre for Plant Protection Studies, Tamil Nadu Agricultural University, Coimbatore 641-003, Tamil Nadu, INDIA, E-mail: umapathy@tnau.ac.in, ORCID No: 0000-0002-5616-4544

${ }^{3}$ Tapioca and Castor Research Station, Affiliated to Tamil Nadu Agricultural University, Yethapur, Salem 636-119, Tamil Nadu, INDIA, E-mail: entosaravanan@gmail.com, ORCID No: 0000-0001-8789-4497
\end{abstract}

Geliş Tarihi / Received: 27.09.2021 Kabul Tarihi / Accepted: 11.10.2021

DOI: 10.31467/uluaricilik.1001135

\section{ABSTRACT}

In an experiment conducted to evaluate the efficacy of four botanical extracts (Solvent extraction) viz., Sweet flag (Acorus calamus), Turmeric (Curcuma longa), Sweet basil (Ocimum basilicum), Medicinal Coleus (Coleus forskohlii) in comparison with three Essential oils (Steam distillation) viz., Eucalyptus (Eucalyptus globulus), Peppermint (Mentha piperita) and Lemongrass (Cymbopogan citratus) against the greater wax moth, Galleria mellonella, it was observed that Sweet basil, 0 . basilicum at $5 \%$ was found to be effective against $G$. mellonella with a maximum of $89.29 \%$ larval mortality followed by Sweet flag (A. calamus) with $65.71 \%$ mortality. Medicinal coleus, (C. forskohlii) with $56.66 \%$ mortality and Turmeric (C. longa) with $45.47 \%$ mortality in the descending order of efficacy. Among essential oils tried, Peppermint oil (M. piperita) has resulted in $\mathbf{8 0 . 2 4 \%}$ larval mortality, followed by Eucalyptus oil (E. globulus) with $69.05 \%$ mortality and Lemongrass oil, C. citratus $(50.48 \%)$. The botanical treatment with Sweet basil, $O$. basilicum $(21.81 \%)$ resulted in minimum comb weight loss by $G$. mellonella followed by Sweet flag, A. calamus (29.04\%). Among the essential oil, Peppermint oil, $M$. piperita (24.56\%) afforded less comb weight loss, indicating the effectiveness of treatment in controlling the larval damage.

Key words: Galleria mellonella L., Botanicals, Essential oils, Larval mortality

\section{ÖZ}

Dört botanik ekstraktın (Çözücü ekstraksiyonu) etkinliğini değerlendirmek için yapılan bir deneyde, Tatlı bayrak (Acorus hint kamışı), Zerdeçal (Curcuma longa), Tatlı fesleğen (Ocimum basilicum), tıbbi Coleus (Coleus forskohlii) üç Essential ile karşılaştırıldığında yağları (Steam distilasyon) yani, Okaliptüs (Eucalyptus globulus), Nane (Mentha piperita) ve Limon otu (Cymbopogan citratus) büyük mum güvesi Galleria mellonella'ya mücadelesi için karşılaştırılmıştır. Tatlı fesleğen, $O$. basilicum'un \%5 oranında G. mellonella'ya karşı maksimum \%89.29 larva ölüm oranı ile etkili, bunu \%65.71 ölüm oranı ile Tatlı bayrak (A. hint kamışı), azalan etkinlik sırasına göre \%56.66 ölüm oranı ile tıbbi coleus (C. forskohlii) ve \%45.47 ölüm oranı ile Zerdeçal (C. longa) takip etmektedir. Denenen uçucu yağlar 
arasında Nane yağı (M. piperita) \%80.24 larva ölümü ile sonuçlanmıştır. Bunu \%69.05 ölüm oranı ile Okaliptüs yağı (E. globulus) ve Limon otu yağı, C. citratus $(\% 50.48)$ izlemiştir. Tatı ıesleğen, $O$. basilicum (\%21.81) ile yapılan botanik tedavi, G. mellonella tarafından minimum petek ağırlığı kaybı ve ardından Sweet flag, A. kalamus (\%29.04) ile sonuçlandı. Uçucu yağlar arasında, Nane yağı, M. piperita (\%24.56), daha az petek ağırığı kaybı sağladı, ve bu da tedavinin larva hasarını kontrol etmedeki etkinliğini göstermektedir.

Anahtar kelimeler: Galleria mellonella L., Bitkiler, Uçucu yağlar, Larva ölümleri

\section{GENIŞLETILMIŞ ÖZET}

Çalışmanın amacı: Balmumu güvesi, Galleria mellonella Linnaeus, bal arısı kolonilerine yönelik, kolonilerin tamamen yok olmasına ve bal verimi kaybına yol açan ciddi tehditlerden biridir. Balın kirlenmesine neden olan balmumu güvelerini kontrol etmek için sentetik pestisitlerin kullanılması, bal arısı kolonileri ve hedef olmayan organizmalar üzerinde zararlı etkileri olmaktadır. Bu sorunları üstesinden gelmek için çevre dostu botanik böcek öldürücüler kullanılabilir. Sonuç olarak, büyük mum güvesini ekonomik olduğu kadar verimli bir şekilde yönetebiliriz.

Malzemeler ve yöntemler: Botanik özler ve uçucu yağlar kullanılarak depolanan koşullar altında daha büyük mum güvesini kontrol etmek için bir deney yapıldı. Bu amaçla, kitle çoğaltma için etkilenen arı kolonilerinden daha büyük balmumu güvesi larvalarını topladık. Kafes koşullarında larvalar mumlu taraklarla beslendi. Erginlerin ortaya çıkmasından sonra çiftleşme kafesine bırakıldılar. Yumurtalar bu kafesten toplandı ve yumurtadan çıkmalarına izin verildi. Bu işleme biyoanaliz tamamlanana kadar devam edildi. Tıbbi ve aromatik bitkilerin yapraklarından botanik ekstraktların ve uçucu yağların hazırlanmasında Mikrodalga destekli distilasyon ünitesi ve buhar distilasyon ünitesi kullanılmıştır. Örnekler tarladan toplandı ve birkaç gün kurutuldu. Kurutulduktan sonra numuneler, çözücü olarak hekzan varlığında damıtma işlemi için ince toz haline getirildi. Seçilen bitkisel özütlerin etkinliğini belirlemek için balmumu peteklerine püskürtülen ekstraktlar ve larvaların beslenmesine izin verildi. Daha sonra ölüm yüzdesi, püskürtmeden 48 saat sonra hesaplandı. Aynı zamanda, $G$. mellonella'nın hasar potansiyelini bulmak için peteğin son ağırlığı da kaydedildi.

Sonuçlar: Denenen botanik ekstraktlardan Tatlı fesleğen ( $O$. basilicum), G. mellonella'nın yönetiminde en yüksek ölüm oranı (\%89.29) ve daha düşük hasar potansiyeli (\%21.81) açısından etkili bulunmuş, bunu Sweet flag (A), Hint kamışı \%65.71 ölüm oranı ve \%29.04 hasar ile izlemiştir. Uçucu yağlar söz konusu olduğunda, Nane ( $M$. piperita) $\% 80.24$ larva ölümü ve \%24.56 ile minimum zarar potansiyeli bildirmiştir. Potansiyel böcek öldürücü özelliklere sahip olmaları nedeniyle, bu iki botanik $G$. mellonella'nın çevre dostu yönetimi için önerilebilir.

Çözüm: Mevcut çalışmamız, depolama koşullarında G. mellonella'yı kontrol etmek için botanik insektisitlerin en iyi alternatif olduğunu ortaya koymuştur. Hedef dışı organizmalar ve insanlar için tehlikeli bir etki oluşturmazlar. Botanik böcek öldürücülerin konsantrasyonunu artırarak, en yüksek ölüm yüzdesine sahip olabiliriz.

\section{INTRODUCTION}

Honey bees (Apis sp.) are the effective pollinators and potential resource-insects known for their abundant offerings of honey, wax, propolis, royal jelly, etc. and hence bee keeping is one of the economically viable ventures. Among many factors challenging bee keeping, two species of wax moth viz, Greater wax moth, Galleria mellonella L. and Lesser wax moth, Achroia grisella L. are considered to be harmful to bee combs both under field and storage conditions.

The larvae of wax moths are potential threat to bee keeping due to their damage by feeding on wax, pollen and larvae of honeybees (Milam 1970). The use of chemical pesticides such as Para Dichloro Benzene, Sulphur and Calcium Cyanide are harmful to honeybee colonies (Grout 1946; Whitcomb 1967). Due to the toxicological hazards of synthetic pesticides to honey bees and their hive products, contamination and persistence could be the global challenges (Pirali and Silva 2010). During severe infestation, the combs get destroyed which leads to the absconding of bee colonies. Infestation of wax moth was recorded about $90 \%$ in the combs of Apis dorsata (Mahindre 1983) and in case of $A$. mellifera colonies it was about $16-19 \%$ (Brar et al. 1985). To protect human health and environmental quality, 


\section{ARAŞTIRMA MAKALESI / RESEARCH ARTICLE}

natural plant based products especially essentials oils are subjected to control the Insect pests (Currie and Gatien 2006). Plant based insecticides are having potential impact on the control of Galleria mellonella (Bolchi 1979; Eischen and Dietz 1987). The botanical pesticides are encouraged over chemical pesticides because of having less toxicity to non-target organisms and the capacity to degrade quickly (Isman 2006).

\section{MATERIALS AND METHODS}

\section{Experimental location}

The experiment was conducted at the Apiary of Tamil Nadu Agricultural University, Coimbatore, Tamil Nadu, India during April 2021.

\section{Mass culturing of Greater wax moth}

The greater wax moth larvae were mass reared on aged honey combs in insect cages, under laboratory conditions, at an ambient temperature of $27 \pm 1^{\circ} \mathrm{C}$. The plastic insect rearing boxes were used for mass culturing of $G$. mellonella. Based on the length and size of the larvae, different instars (Fig. 2d) were identified. The larval length and diameter ranges from $1-30 \mathrm{~mm}$ and $0.12-7.0 \mathrm{~mm}$ respectively (Paddock 1918). The later instar larvae (Fig. 2b\&c) begin to spin the cocoon (Fig. 3a) and pupate inside that. Larval development lasts 6-7 weeks. The pupation was on the edges of the plastic lid. The pupal development of greater wax moth ranges from 6-55 days and it varies with season and temperature (Williams, 1997). Mostly, growth and size increase occur during the last 2 instars. There are 7 larval moults throughout its development (Ellis et al. 2013). After the emergence of adult (Fig. 4), moths were transferred into the separate plastic container for the purpose of mating process. The paper bits were added into that mating cage to provide the surface for egg laying (Fig. 1b). Eggs are laid in clusters (Fig. 1a). The newly hatched larvae (Fig. 2a) were allowed to grow continuously and the larvae thus cultured were utilized for assessing the efficacy of botanicals viz., A. calamus (Sweet flag), C. longa (Turmeric), $O$. basilicum (Sweet basil), C. forskohlii (Medicinal coleus), E. globulus (Eucalyptus), M. piperita (Peppermint) and C. citratus (Lemongrass) for the management of $G$. mellonella.

\section{Preparation of botanical extracts and essential oils}

The plant samples (Table 1) were obtained from the field at germplasm collections maintained by the department of medicinal plants and aromatic crops and botanical garden of TNAU.

Table 1. List of medicinal and aromatic plants used against the Greater wax moth, G. mellonella

\begin{tabular}{|c|c|c|c|c|}
\hline SI. No. & Common name & Botanical name & Family & Plant parts used \\
\hline 1. & Sweet flag & Acorus calamus & Acoraceae & Rhizome \\
\hline 2. & Turmeric & Curcuma longa & Zingiberaceae & Rhizome \\
\hline 3. & Sweet basil & Ocimum basilicum & Lamiaceae & Leaves \\
\hline 4. & Medicinal coleus & Coleus forskohlii & Lamiaceae & Leaves \\
\hline 5. & Eucalyptus & Eucalyptus globulus & Myrtaceae & Leaves \\
\hline 6. & Peppermint & Mentha piperita & Lamiaceae & Poaceae \\
\hline 7. & Lemongrass & Cymbopogan citratus & & \\
\hline
\end{tabular}

The plant samples were collected, shade dried for 45 days, ground into powder and plant extracts were obtained by using microwave assisted extraction unit. A sample of $2 \mathrm{gm}$ each of the plant powder was weighed and put into the extraction cells along with $20 \mathrm{ml}$ Hexane as a solvent. The extraction cells were then fixed into the unit and the process was continued for one hour. Later, the plant extracts were collected from the unit and filtered with Whatman filter paper. Essential oils were extracted by steam distillation, which is the most common way to extract aromatic compounds from a plant. The combination of heated steam and gentle pressure allows the essential oil to be released from the microscopic 


\section{ARAŞTIRMA MAKALESI / RESEARCH ARTICLE}

protective sacs of plant samples. As the vapour mixture flows through a condenser and cools, it yields a layer of oil and a layer of water. The essential oil rises to the top and was separated from the water.

\section{Bioassay}

Different concentrations of plant extracts $(A$. calamus, $C$. longa, $O$. basilicum and $C$. forskohlii) and essential oils (E. globulus, M. piperita and $C$. citratus)were prepared for fixing effective dose to evaluate the bio-efficacy of selected plant extracts against different instars of wax moth larvae. Accordingly, different concentration levels viz., $2 \%$, $3 \%$ and $5 \%$ were prepared by suitable dilution with distilled water for plant extracts and a preliminary bioassay was conducted on a piece of old comb consisting of 100 larvae without segregating instars. Based on the observation of larval mortality, the 5\% concentration was fixed to be tested against different instars. The aged or dark honey combs were cut into 5 gram weighed rectangular (35sq.cm) pieces and placed into the plastic containers. Each instar of wax moth larvae at 20 numbers. were released onto uniform size aged comb pieces and the treatments were imposed by giving a spray $(1 \mathrm{ml})$ by using an atomiser. After spraying, the combs were allowed for drying at room temperature. Each treatment was replicated thrice. Observations on larval mortality were taken 48 hours after spray and the larval mortality (\%) was calculated (Taye and Mekonen, 2019).

\section{Assessment of damage potential of Greater wax moth}

The effectiveness of treatments was assessed by allowing 20 numbers of larvae on $5 \mathrm{gm}$ of aged treated combs without any hive products for 2 days and the final weight was assessed on $3^{\text {rd }}$ day. The weight loss (\%) assessment was done by calculating the difference between initial and final weight of the comb allowed for feeding by $G$. mellonella.

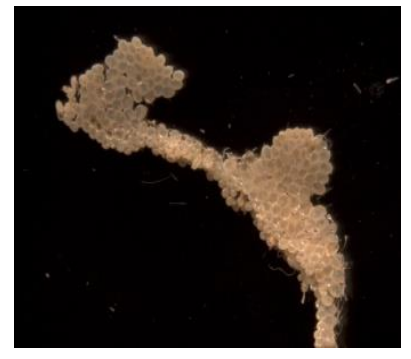

(a) Egg clusters

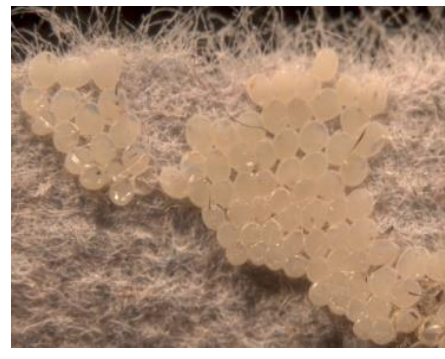

(b) Eggs laid on filter paper bits

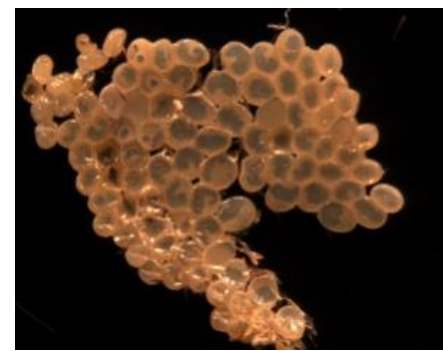

(c) Eggs, Ready to hatch

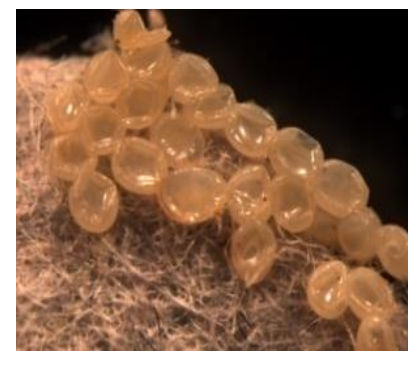

(d) Hatched eggs

Figure 1. Eggs of Greater wax moth, G. mellonella

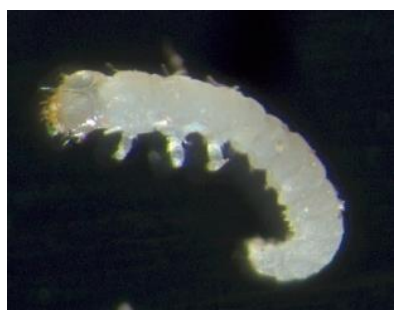

(a) Neonate larva

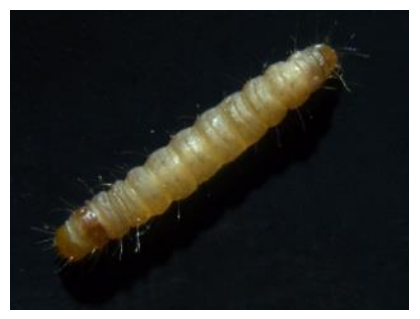

(b) Matured larva (Dorsal)

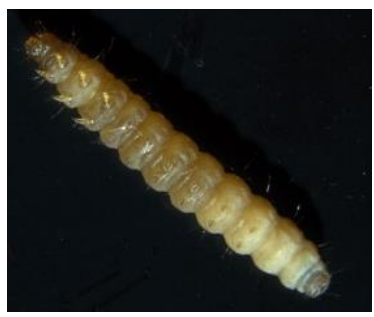

(c) Matured larva (Ventral)

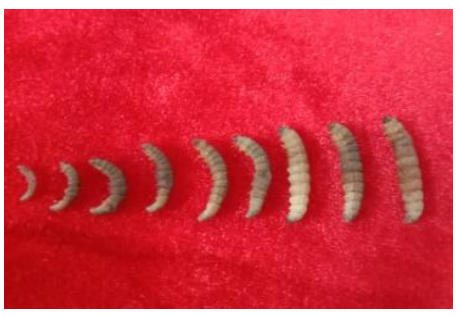

(d) Different instars of larvae

Figure 2. Larvae of Greater wax moth, G. mellonella 


\section{ARAŞTIRMA MAKALESI / RESEARCH ARTICLE}

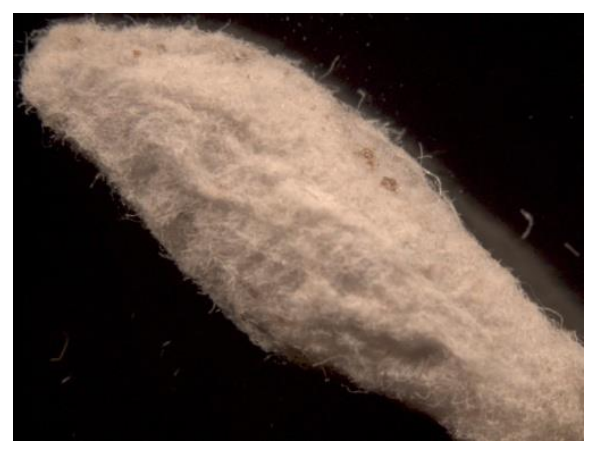

(a) Pupa covered by Silken cocoon

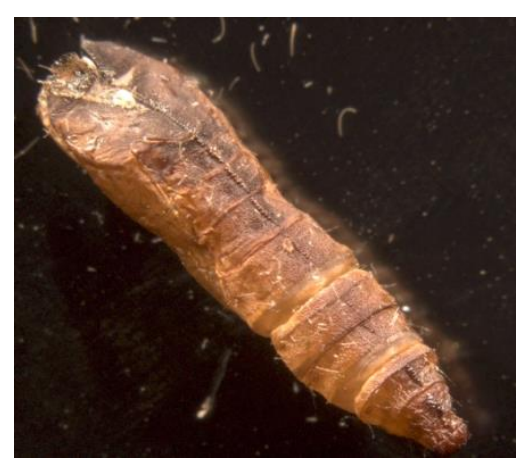

(b) Obtect type of pupa

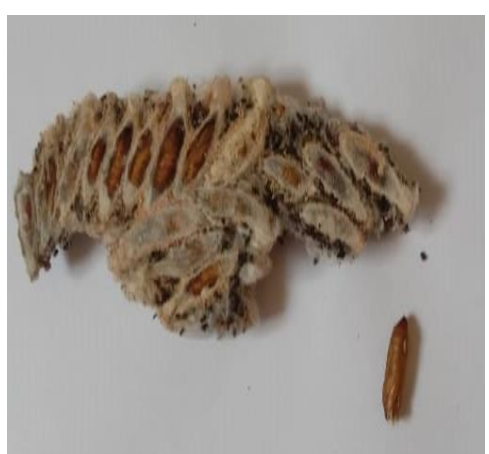

(c) Cluster of pupae

Figure 3. Pupa of Greater wax moth, G. mellonella

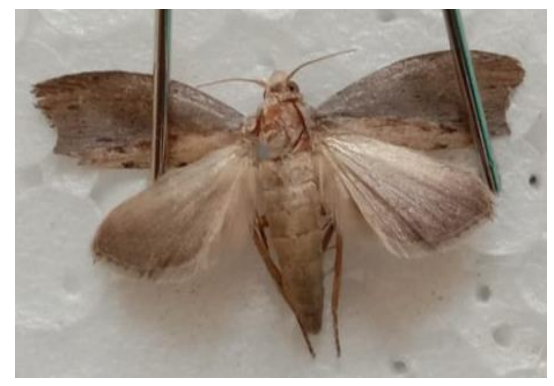

(a) Adult male

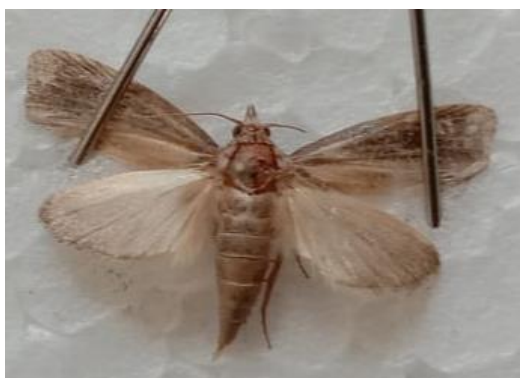

(b) Adult female

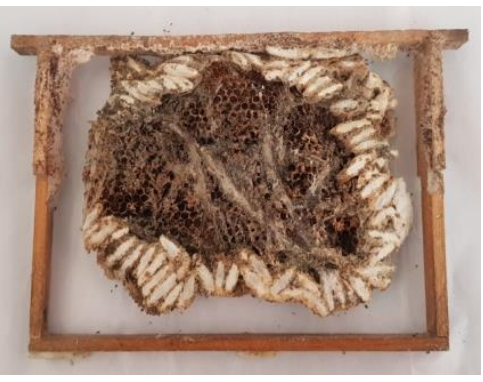

Figure 5. Combs affected by G. mellonella

Figure 4. Adult of Greater wax moth, G. mellonella

\section{Statistical Analysis}

The experiments were laid in Completely Randomized Block Design (CRBD) with three replications and the data were statistically analyzed by Analysis of Variance (ANOVA) techniques (Khan and Khanum, 1994) and means were ordered by Duncan's Multiple Range Test (DMRT).

\section{RESULTS}

\section{Efficacy of botanical extracts and essential oils against G. mellonella}

According to the results (Table 2), an experiment on bioefficacy of medicinal and aromatic plant extracts against the greater wax moth, G. mellonella exhibited the effectiveness (Fig. 6) O. basilicum with $89.29 \%$ larval motality followed by, $A$. calamus (65.71\%), C. forskohlii (56.66\%) and C. longa
(45.47\%). Maximum reduction over control (\%) was recorded in 0 . basilicum (88.47\%) followed by $M$. piperita (78.70\%), while least reduction (\%) was recorded with $C$. longa $(45.47 \%)$. Highest larval mortality (\%) with 0 . basilicum might have done because of its insecticidal and anti-feedant properties against insects (Hussein and Abdelwahab, 2015)

Among the essential oils, $M$. piperita performed well against wax moth larvae with $80.24 \%$ kill of larvae, which is in line with the earlier findings (Hussein and Abdelwahab 2015). M. piperita was ranged from 29 to $79 \%$ which supports our research findings. Peppermint species have been reported to have potential insecticidal properties and act as an excellent repellent for insects (Kumar et al. 2011). Followed by $M$. piperita, E. globulus and C. citratus with $69.05 \%$ and $50.48 \%$ larval mortality respectively. 


\section{ARAŞTIRMA MAKALESI / RESEARCH ARTICLE}

\section{Per cent damage by G. mellonella with botanical} extracts and essential oils

In another experiment on the comb weight loss due to larval damage in the botanical treatments (Table 3 ), the supremacy of $O$. basilicum extract which recorded a least weight loss of $21.81 \%$. The order of efficacy (Fig. 7) of botanical treatments in terms of comb damage was, $O$. basilicum (21.81\%), $M$. piperita $(24.56 \%)$, E. globulus $(29.95 \%)$, A. calamus (29.04\%), C. forskohlii (31.34\%), C. citratus $(32.51 \%)$ and C. longa (33.47\%) which is in conformity with the findings of Hussein and Abdelwahab (2015).

Table 2. Efficacy of medicinal and aromatic plant extracts and essential oils on different larval instars of Greater wax moth, G. mellonella

\begin{tabular}{|c|c|c|c|c|c|c|c|c|c|}
\hline \multirow{2}{*}{ Treatment } & \multicolumn{7}{|c|}{$\%$ larval mortality of different larval instars* $\pm S . D$} & \multirow{2}{*}{$\begin{array}{l}\text { Overall } \\
\text { Mean }\end{array}$} & \multirow{2}{*}{$\begin{array}{c}\text { Reduction } \\
\text { over } \\
\text { control (\%) }\end{array}$} \\
\hline & I & II & III & IV & $\mathrm{V}$ & $\mathrm{VI}$ & VII & & \\
\hline \multicolumn{10}{|c|}{ Plant extracts } \\
\hline $\begin{array}{l}\text { Acorus } \\
\text { calamus }\end{array}$ & $\begin{array}{l}86.67 \pm 2.89 \\
(68.67)^{b c}\end{array}$ & $\begin{array}{l}75.00 \pm 5.0 \\
(60.07)^{\mathrm{bc}}\end{array}$ & $\begin{array}{l}70.00 \pm 5.12 \\
(56.84)^{\mathrm{cd}}\end{array}$ & $\begin{array}{l}66.67 \pm 7.64 \\
(54.83)^{\mathrm{cd}}\end{array}$ & $\begin{array}{l}58.33 \pm 5.77 \\
(49.82)^{\mathrm{cd}}\end{array}$ & $\begin{array}{l}53.33 \pm 5.73 \\
(46.92)^{\mathrm{cd}}\end{array}$ & $\begin{array}{l}50.00 \pm 8.66 \\
(45.01)^{c}\end{array}$ & 65.71 & 63.07 \\
\hline $\begin{array}{l}\text { Curcuma } \\
\text { longa }\end{array}$ & $\begin{array}{l}68.33 \pm 7.64 \\
(55.85)^{d}\end{array}$ & $\begin{array}{l}58.33 \pm 5.77 \\
(49.82)^{d}\end{array}$ & $\begin{array}{l}48.33 \pm 5.73 \\
(44.04)^{f}\end{array}$ & $\begin{array}{l}48.33 \pm 5.77 \\
(44.04)^{e}\end{array}$ & $\begin{array}{l}40.00 \pm 5.00 \\
(39.21)^{f}\end{array}$ & $\begin{array}{l}31.67 \pm 7.64 \\
(34.15)^{\mathrm{e}}\end{array}$ & $\begin{array}{l}23.33 \pm 2.89 \\
(28.86)^{f}\end{array}$ & 45.47 & 41.28 \\
\hline $\begin{array}{l}\text { Ocimum } \\
\text { basilicum }\end{array}$ & $\begin{array}{l}100.00 \pm 0.0 \\
(89.71)^{a}\end{array}$ & $\begin{array}{l}98.33 \pm 2.89 \\
(85.50)^{a}\end{array}$ & $\begin{array}{l}98.33 \pm 2.81 \\
(85.50)^{a}\end{array}$ & $\begin{array}{l}88.33 \pm 2.89 \\
(70.12)^{a}\end{array}$ & $\begin{array}{l}86.67 \pm 2.88 \\
(68.67)^{a}\end{array}$ & $\begin{array}{l}81.67 \pm 2.84 \\
(64.69)^{a}\end{array}$ & $\begin{array}{l}71.67 \pm 2.89 \\
(57.86)^{a}\end{array}$ & 89.29 & 88.47 \\
\hline $\begin{array}{l}\text { Coleus } \\
\text { forskohlii }\end{array}$ & $\begin{array}{l}78.33 \pm 2.88 \\
(62.29)^{\mathrm{cd}}\end{array}$ & $\begin{array}{l}68.33 \pm 2.84 \\
(55.77)^{\mathrm{cd}}\end{array}$ & $\begin{array}{l}60.00 \pm 5.00 \\
(50.79)^{\mathrm{de}}\end{array}$ & $\begin{array}{l}58.33 \pm 7.64 \\
(49.83)^{\mathrm{de}}\end{array}$ & $\begin{array}{l}53.33 \pm 5.77 \\
(46.92)^{\mathrm{de}}\end{array}$ & $\begin{array}{l}38.33 \pm 5.70 \\
(38.22)^{d}\end{array}$ & $\begin{array}{l}40.00 \pm 5.00 \\
(39.21)^{\mathrm{de}}\end{array}$ & 56.66 & 53.33 \\
\hline & & & & Essentia & oils & & & & \\
\hline $\begin{array}{l}\text { Eucalyptus } \\
\text { globulus }\end{array}$ & $\begin{array}{l}91.67 \pm 2.89 \\
(73.40)^{b}\end{array}$ & $\begin{array}{l}85.00 \pm 5.0 \\
(67.41)^{b}\end{array}$ & $\begin{array}{l}76.66 \pm 2.89 \\
(61.15)^{c}\end{array}$ & $\begin{array}{l}73.33 \pm 7.64 \\
(59.06)^{\mathrm{bc}}\end{array}$ & $\begin{array}{l}63.33 \pm 2.89 \\
(52.74)^{c}\end{array}$ & $\begin{array}{l}46.67 \pm 7.60 \\
(43.08)^{\mathrm{bc}}\end{array}$ & $\begin{array}{l}46.67 \pm 7.64 \\
(43.08)^{\mathrm{cd}}\end{array}$ & 69.05 & 66.67 \\
\hline $\begin{array}{l}\text { Mentha } \\
\text { piperita }\end{array}$ & $\begin{array}{l}98.33 \pm 2.89 \\
(85.50)^{a}\end{array}$ & $\begin{array}{l}96.67 \pm 2.89 \\
(81.29)^{a}\end{array}$ & $\begin{array}{l}91.66 \pm 2.80 \\
(73.40)^{\mathrm{b}}\end{array}$ & $\begin{array}{l}78.33 \pm 5.77 \\
(62.41)^{b}\end{array}$ & $\begin{array}{l}70.00 \pm 5.00 \\
(56.84)^{\mathrm{b}}\end{array}$ & $\begin{array}{l}65.00 \pm 5.00 \\
(53.76)^{b}\end{array}$ & $\begin{array}{l}61.67 \pm 2.89 \\
(51.76)^{b}\end{array}$ & 80.24 & 78.70 \\
\hline $\begin{array}{l}\text { Cymbopogan } \\
\text { citratus }\end{array}$ & $\begin{array}{l}58.33 \pm 5.77 \\
(62.40)^{\mathrm{cd}}\end{array}$ & $\begin{array}{l}66.67 \pm 5.77 \\
(54.79)^{\mathrm{cd}}\end{array}$ & $\begin{array}{l}53.33 \pm 2.89 \\
(46.91)^{\mathrm{ef}}\end{array}$ & $\begin{array}{l}55.00 \pm 5.00 \\
(47.88)^{\mathrm{e}}\end{array}$ & $\begin{array}{l}51.67 \pm 7.64 \\
(45.97)^{\mathrm{ef}}\end{array}$ & $\begin{array}{l}36.67 \pm 5.77 \\
(37.22)^{d}\end{array}$ & $\begin{array}{l}31.67 \pm 5.77 \\
(34.18)^{\mathrm{ef}}\end{array}$ & 50.48 & 46.67 \\
\hline $\begin{array}{l}\text { Control } \\
\text { (Water) }\end{array}$ & $\begin{array}{l}11.67 \pm 2.89 \\
(19.89)^{\mathrm{e}}\end{array}$ & $\begin{array}{l}6.67 \pm 2.89 \\
(14.76)^{\mathrm{e}}\end{array}$ & $\begin{array}{l}6.67 \pm 2.89 \\
(14.76)^{g}\end{array}$ & $\begin{array}{l}8.33 \pm 2.45 \\
(16.60)^{f}\end{array}$ & $\begin{array}{l}6.67 \pm 2.36 \\
(14.76)^{g}\end{array}$ & $\begin{array}{l}5.00 \pm 0.0 \\
(12.92)^{f}\end{array}$ & $\begin{array}{l}5.00 \pm 0.0 \\
(12.92)^{\mathrm{g}}\end{array}$ & 7.14 & - \\
\hline SEm \pm & 14.90 & 21.30 & 13.69 & 14.91 & 9.96 & 11.22 & 9.52 & - & - \\
\hline C.D $(p=0.05)$ & 6.62 & 8.00 & 6.41 & 6.68 & 5.46 & 5.80 & 5.34 & - & - \\
\hline
\end{tabular}

Note: * Mean of three replications for each instar. Figures in parentheses are arc sine transformed values; S.D: Standard Deviation; SEm: Standard Error of mean; C.D: Critical Difference. Figures are not having the same alphabetical letters in a same column differ significantly at $p<0.05$. 


\section{ARAŞTIRMA MAKALESI / RESEARCH ARTICLE}

Table 3. Weight reduction of comb (\%) by Greater wax moth, G. mellonella

\begin{tabular}{|c|c|c|c|c|c|c|c|c|}
\hline \multirow{2}{*}{ Treatment } & \multicolumn{7}{|c|}{ (\%) weight reduction of comb by different larval intars of Galleria mellonella** } & \multirow[t]{2}{*}{ Overall Mean } \\
\hline & I & II & III & IV & V & VI & VII & \\
\hline \multicolumn{9}{|c|}{ Plant extracts } \\
\hline Acorus calamus & $\begin{array}{c}3.30 \\
(1.82)^{\mathrm{cd}}\end{array}$ & $\begin{array}{c}5.87 \\
(2.42)^{\mathrm{cd}}\end{array}$ & $\begin{array}{c}6.60 \\
(14.89)^{d}\end{array}$ & $\begin{array}{c}19.73 \\
(26.37)^{d}\end{array}$ & $\begin{array}{c}47.77 \\
(43.71)^{d}\end{array}$ & $\begin{array}{c}56.43 \\
(48.70)^{\mathrm{e}}\end{array}$ & $\begin{array}{c}63.60 \\
(52.89)^{\mathrm{e}}\end{array}$ & 29.04 \\
\hline Curcuma longa & $\begin{array}{c}6.17 \\
(2.48)^{\mathrm{b}}\end{array}$ & $\begin{array}{c}7.97 \\
(2.82)^{\mathrm{b}}\end{array}$ & $\begin{array}{c}9.97 \\
(18.38)^{b}\end{array}$ & $\begin{array}{c}22.53 \\
(28.34)^{b}\end{array}$ & $\begin{array}{c}55.70 \\
(48.27)^{\mathrm{b}}\end{array}$ & $\begin{array}{c}61.53 \\
(51.67)^{\mathrm{b}}\end{array}$ & $\begin{array}{c}70.43 \\
(57.06)^{\mathrm{b}}\end{array}$ & 33.47 \\
\hline Ocimum basilicum & $\begin{array}{c}0.83 \\
(0.91)^{\dagger}\end{array}$ & $\begin{array}{c}2.90 \\
(1.70)^{\dagger}\end{array}$ & $\begin{array}{c}2.37 \\
(8.78)^{\mathrm{e}}\end{array}$ & $\begin{array}{c}15.87 \\
(23.47)^{\mathrm{e}}\end{array}$ & $\begin{array}{c}29.57 \\
(32.93)^{f}\end{array}$ & $\begin{array}{c}43.43 \\
(41.22)^{g}\end{array}$ & $\begin{array}{c}57.70 \\
(49.43)^{f}\end{array}$ & 21.81 \\
\hline Coleus forskohlii & $\begin{array}{c}3.80 \\
(1.95)^{\mathrm{c}}\end{array}$ & $\begin{array}{c}6.00 \\
(2.45)^{\mathrm{cd}}\end{array}$ & $\begin{array}{c}7.50 \\
(7.50)^{\mathrm{cd}}\end{array}$ & $\begin{array}{c}21.93 \\
(27.92)^{b c}\end{array}$ & $\begin{array}{c}52.10 \\
(46.20)^{\mathrm{bcd}}\end{array}$ & $\begin{array}{c}59.50 \\
(50.48)^{c}\end{array}$ & $\begin{array}{c}68.53 \\
(55.88)^{c}\end{array}$ & 31.34 \\
\hline & & & Ess & ntial oils & & & & \\
\hline Eucalyptus globulus & $\begin{array}{c}2.77 \\
(1.66)^{d}\end{array}$ & $\begin{array}{c}5.77 \\
(2.40)^{d}\end{array}$ & $\begin{array}{c}6.47 \\
(14.73)^{d}\end{array}$ & $\begin{array}{c}20.57 \\
(26.96)^{\mathrm{cd}}\end{array}$ & $\begin{array}{c}50.33 \\
(45.19)^{c d}\end{array}$ & $\begin{array}{c}58.30 \\
(49.78)^{d}\end{array}$ & $\begin{array}{c}65.47 \\
(54.01)^{d}\end{array}$ & 29.95 \\
\hline Mentha piperita & $\begin{array}{c}1.77 \\
(1.30)^{\mathrm{e}}\end{array}$ & $\begin{array}{c}3.50 \\
(1.87)^{\mathrm{e}}\end{array}$ & $\begin{array}{c}3.43 \\
(10.65)^{\mathrm{e}}\end{array}$ & $\begin{array}{c}17.20 \\
(24.50)^{\mathrm{e}}\end{array}$ & $\begin{array}{c}39.63 \\
(39.01)^{\mathrm{e}}\end{array}$ & $\begin{array}{c}47.87 \\
(43.78)^{f}\end{array}$ & $\begin{array}{c}58.53 \\
(49.91)^{f}\end{array}$ & 24.56 \\
\hline Cymbopogan citratus & $\begin{array}{c}5.47 \\
(2.34)^{\mathrm{b}}\end{array}$ & $\begin{array}{c}6.47 \\
(2.54)^{c}\end{array}$ & $\begin{array}{c}8.93 \\
(17.38)^{b c}\end{array}$ & $\begin{array}{c}22.27 \\
(28.15)^{b}\end{array}$ & $\begin{array}{c}53.20 \\
(46.84)^{\mathrm{bc}}\end{array}$ & $\begin{array}{c}61.90 \\
(51.89)^{\mathrm{b}}\end{array}$ & $\begin{array}{c}69.30 \\
(56.35)^{\mathrm{bc}}\end{array}$ & 32.51 \\
\hline Control (Water) & $\begin{array}{c}8.80 \\
(2.96)^{\mathrm{a}}\end{array}$ & $\begin{array}{l}11.70 \\
(3.42)^{\mathrm{a}}\end{array}$ & $\begin{array}{c}33.27 \\
(35.18)^{\mathrm{a}}\end{array}$ & $\begin{array}{c}57.53 \\
(49.33)^{\mathrm{a}}\end{array}$ & $\begin{array}{c}73.93 \\
(59.32)^{a}\end{array}$ & $\begin{array}{c}78.83 \\
(62.61)^{a}\end{array}$ & $\begin{array}{c}82.13 \\
(65.01)^{a}\end{array}$ & 49.46 \\
\hline SEm \pm & 0.01 & 0.01 & 1.87 & 0.47 & 2.52 & 0.14 & 0.25 & - \\
\hline C.D $(p=0.05)$ & 0.16 & 0.13 & 2.36 & 1.19 & 2.75 & 0.64 & 0.87 & - \\
\hline
\end{tabular}

Note: ${ }^{* \star}$ Mean of three replications for each instar. Figures in parentheses are arc sine transformed values; SEm: Standard error mean; C.D: Critical difference.

Figures are not having the same alphabetical letters in a same column differ significantly at $p<0.05$. 
ARAŞTIRMA MAKALESİ / RESEARCH ARTICLE

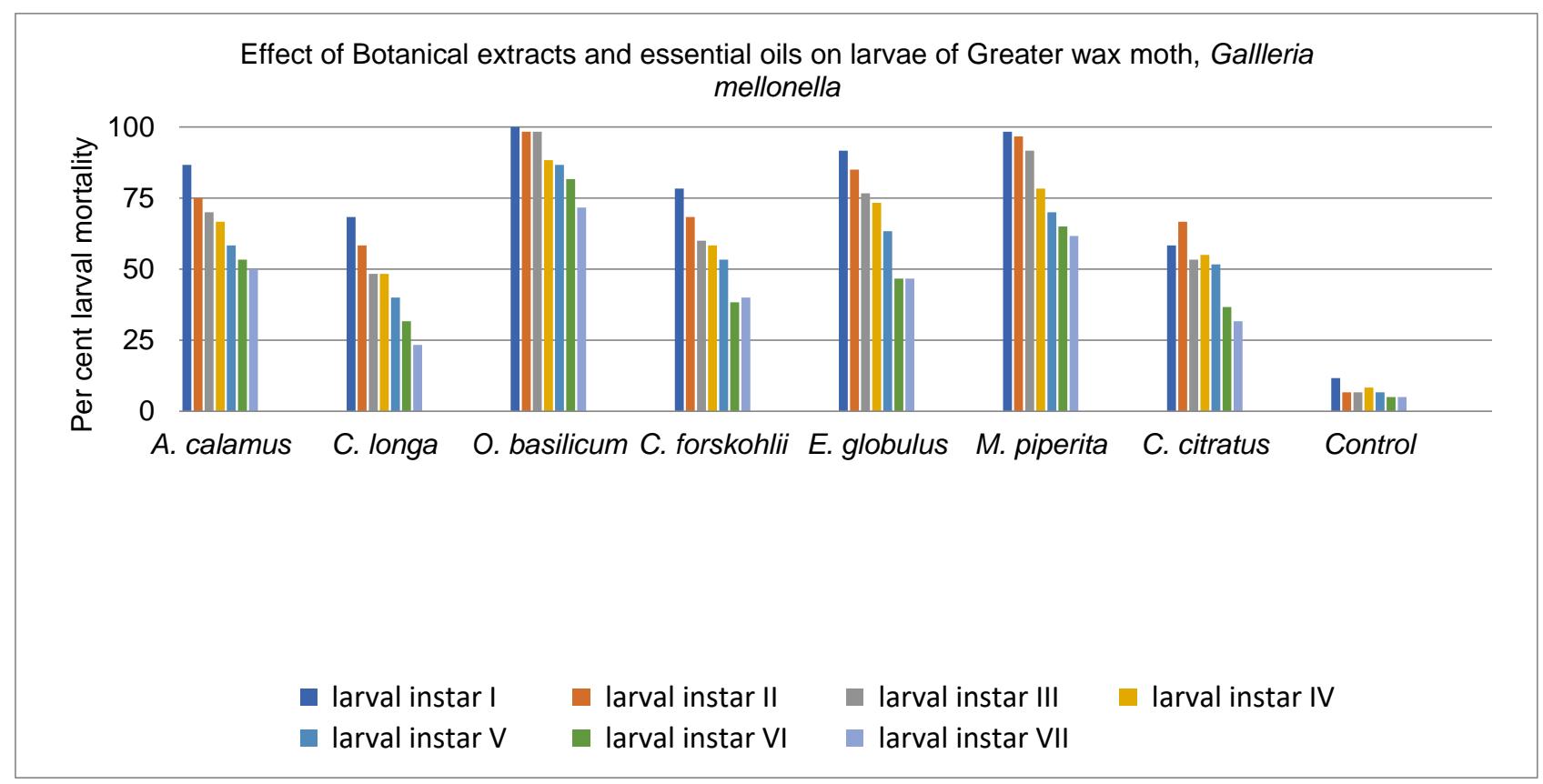

Figure 6. Per cent larval mortality of G. mellonella with different botanical treatments

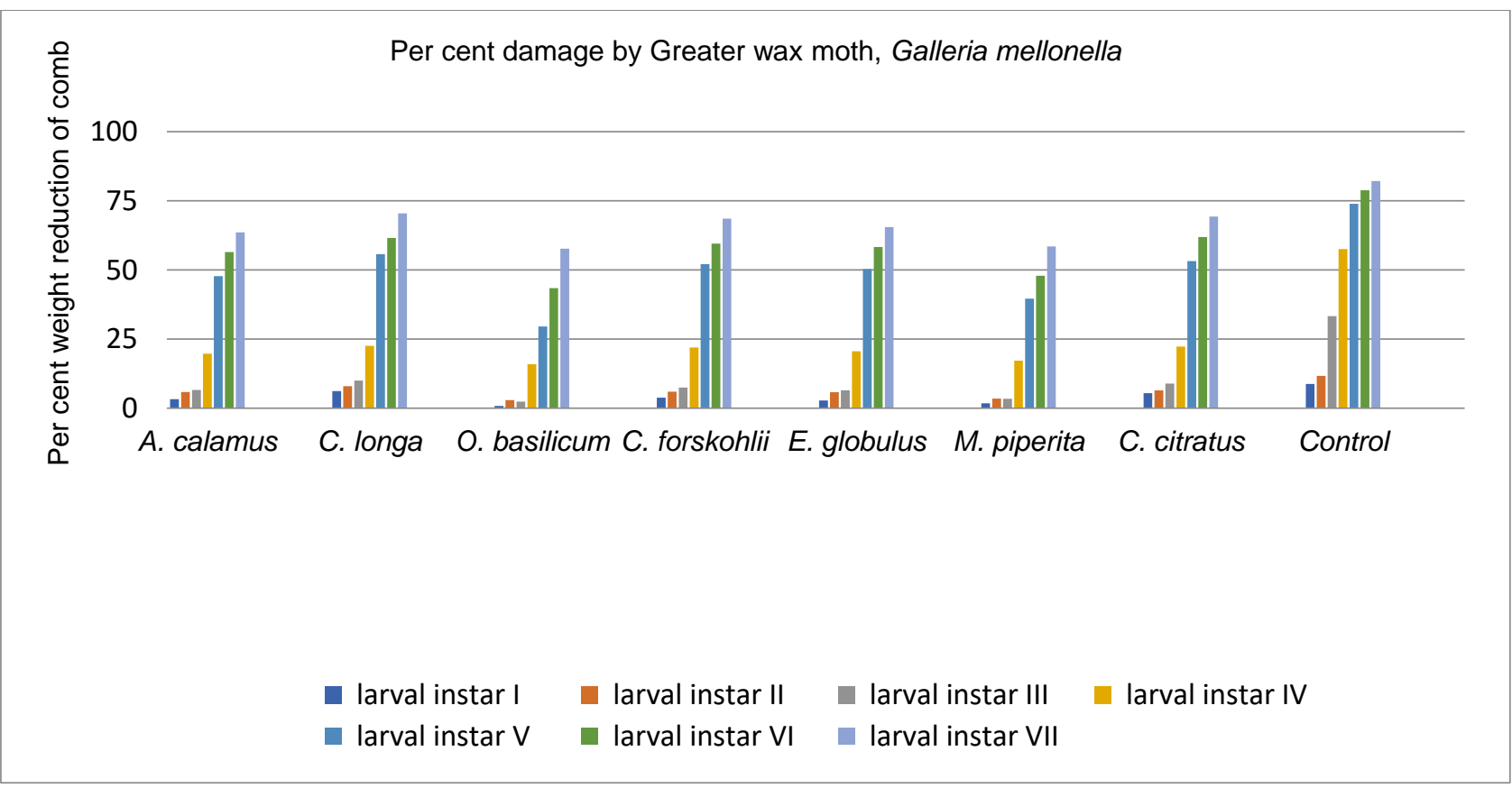

Figure 7. Per cent damage by $G$. mellonella with different botanical treatments 


\section{ARAŞTIRMA MAKALESI / RESEARCH ARTICLE}

\section{Per cent damage by G. mellonella with botanical extracts and essential oils}

In another experiment on the comb weight loss due to larval damage in the botanical treatments (Table 3 ), the supremacy of $O$. basilicum extract which recorded a least weight loss of $21.81 \%$. The order of efficacy of botanical treatments in terms of comb damage was, $O$. basilicum $(21.81 \%)$, M. piperita $(24.56 \%)$, E. globulus $(29.95 \%), \quad$ A. calamus $(29.04 \%), \quad$ C. forskohlii $(31.34 \%), \quad$ C. citratus $(32.51 \%)$ and C. longa (33.47\%) which is in conformity with the findings of Hussein and Abdelwahab (2015).

\section{DISCUSSION}

The botanical extracts viz., $O$. basilicum and $A$. calamus at $5 \%$ were performed better than other plant extracts of $C$. longa and $C$. forskohlii for the management of wax moth under stored conditions. These finding are in accordance with that of Taye and Mekonen (2019) who concluded that leaf extracts of Azadirachta indica and Ocimum basilicum were more effective against greater wax moth, G. mellonella within 48 hours and this might be attributed to their insecticidal, growth regulatory and anti- feedant properties against insects. Among essential oils, the effectiveness of Peppermint oil, $M$. piperita was found promising with $80.24 \%$ mortality of wax moth larvae compared with Eucalyptus and Lemongrass oil. The natural plant based botanicals are more economical and eco-friendly when compared to synthetic chemical pestiicdes. Therefore, leaf extract of Ocimum basilicum and essential oil from Mentha piperita can be exploited as sources for bio-pesticides to control $G$. mellonella. Considering the loss of cells due to larval attack in the treated combs, Sweet basil, $O$. basilicum showed a promising performance due to least comb damage of $21.81 \%$. In the light of inferences obtained from this present investigation, the $O$. basilicum plant extract could be utilized for the eco-friendly management of wax moth under storage conditions.

\section{Conclusion}

Tested Botanical extracts exhibited the greatful response to the different larval instars of greater wax moth, G. mellonella as compared with control. According to the results, $O$. basilicum (Sweet basil) $5 \%$ was found to be effective against greater $G$. mellonella followed by M. piperita (Peppermint) $5 \%$ within $48 \mathrm{hrs}$ as they have potential insecticidal properties (Hussein and Abdelwahab, 2015). These natural plant products never cause any health hazards to non-target organisms as well as human beings and also cost effective. Hence, these botanical extracts can be used for the management of greater wax moth, $G$. mellonella.

Source of finance for the study: Not applicable

Author contribution: Dr. G. Umapathy, Chairman for my research work and Dr. P.A. Saravanan, Coauthor and my member incharge Dr. D. Uma gave patient guidance and immense support to complete my work in a perfect manner. I cordially express my thanks to all.

Conflict of interest: The authors have no conflict of interest to declare.

Ethical issues: Not applicable

\section{Aknowledgement}

I express my sincere gratitude to my beloved chairman, Dr. G. Umapathy, Entomologist (CPPS, TNAU) and my research guide Dr. P.A. Saravanan, Entomologist (TCRS, TNAU) and Dr. D. Uma, Professor and Head (Dept. of Biochemistry, TNAU) for their immense guidance and valuable support throughout my research.

\section{REFERENCES}

Bolchi, G. 1979. Laboratory tests on the activity of muristerone on various insects. Boll. Zoolog. Agrar. Bachicoltura 15: 1-14.

Brar, HS, Gatoria, GS, Jhajj HS, Chahal, BS. 1985. Seasonal infestation of Galleria mellonella and population of Vespa orientalis in Apis mellifera apiaries in Punjab. Indian Journal of Ecology 129: 735-737.

Currie, RW, Gatien, P. 2006. Timing acaricide treatments to prevent Varroa destructor (Acari: Varroidae) from causing economic damage to honey bee colonies, Can. Entomology 138: 238-252.

Ellis, JD, Graham, JR, Mortenson, A. 2013. Standard methods for Wax moth research. J. Apic. Res. 52: 1-17.

Eischen, FA, Dietz, A.1987. Growth and survival of Galleria mellonella (Lepidoptera: Pyralidae) larvae fed on diets containing honey bee collected plant resins. Ann. Entomol. Soc. Amer. 80: 74-77. 


\section{ARAŞTIRMA MAKALESI / RESEARCH ARTICLE}

Grout, RA. 1946. The hive and honey bee, Hamilton, Illinois, U.S.A, pp. 509

Hussein, M, Abdelwahab, I. 2015. Effects of Three Essential Oils and /or Gamma Irradiation on the Greater Wax Moth, Galleria Mellonella. Egypt. Acad. J. Biolog. Sci. 7(1): 37-47

Isman, B. 2006. Botanical insecticides, Deterrents, And Repellents in Modern Agriculture and an Increasingly Regulated World. Annu. Rev. Entomol. 51(1): 45-66.

Khan, IA, Khanum, A. 1994. Fundamentals of Biostatistics. Vkaaz Publication, Hyderabad, India, pp. 3492-431.

Kumar, M, Kumar, Y, Kalpana, B, Raghul, K. 2017. Efficacy of some Essential Oils against the Greater Wax Moth (Galleria mellonella L.) under Storage condition. Environment\& Ecology 35(4): 2760-2763.

Mahindre, DB. 1983. Handling Rock bee colonies. Indian Bee Journal 45: 72-73.
Milam, VG. 1970. Moth pests of honeybee combs. Gleanian Bee Culture 68:424-428.

Paddock, FB. 1918. The Beemoth or Waxworm; Texas Agricultural Experiment Stations: College Station, TX, US.

Pirali, K, Silva, JAT. 2010. Lavandula angustifolia essential oil as a novel and promising natural candidate for Tick (Rhipicephalus annulatus) control. Experimental Parasitology.

Taye, B. and Mekonen, W. 2019. Evaluating the effect of plant extracts against Greater Wax Moth, Galleria mellonella (L). Journal of Natural Sciences Research 9(21): 2224-3186.

Whitcomb, WJ. 1967. Controlling the Greater Wax Moth, A pest of Honeycomb. Bull. U.S. Dept. Agric. 2217: 12.

Williams, JL. 1997. Insects: Lepidoptera (Moths). Honey bee pests, predators and diseases. The Al Root Company; Ohio, USA. 